\title{
Analysis of the scale of the implementation of the energy security threats in Russia up to 2030 and the main directions for the neutralization of these threats
}

\author{
Viktor Rabchuk ${ }^{1}$ and Sergey Senderov ${ }^{1 *}$ \\ ${ }^{1}$ Energy Systems Institute SB RAS, 130 Lermontov str., Irkutsk, Russia
}

\begin{abstract}
In the paper the scales of implementation of strategic threats to energy security are compared for different time stages. The main factors affecting the strengthening or weakening of these threats are shown. The estimation of the country's total needs in primary energy resources and the required volumes of gas to fully cover these needs (taking into account the capabilities of other energy systems of the fuel and energy complex) is made. The total possible levels of Russian gas exports for the future are estimated. The possibilities of fuel and energy complex industries for the perspective satisfaction of the needs of domestic and export consumers are considered in detail.
\end{abstract}

\section{Introduction}

The main requirements for Russia's energy security system (ES) for the next 10-15 years are to create conditions for maintaining the deficit-free energy balance of the country and its regions and to prevent a decrease in the volume of exports of Russian energy resources. The creation of such conditions means the implementation in this perspective of effective measures to neutralize a number of threats to the Russia's ES.

The analysis carried out [1-3, etc.] shows that in the future up to 2030 the country's economy and energy industries, in particular, will experience serious difficulties with investments. Therefore, the measures mentioned above should have special significance for fulfilling the basic requirements of the ES, i.e. these measures should have priority. In this paper, it is proposed to select the direction of the mentioned measures taking into account the results of the evaluation of the nature of the transformation of EB threats on time intervals - from 2020 to 2025 and from 2026 to 2030.

Some researchers in the world have dealt with the identification of the most significant ES threats. For example, this issue is covered in [4-7]. In [4], on the example of India, the authors describe the relationship of energy security with business, social processes and with the management of society. In [5] a look at the main problems of ensuring China's energy security based on the use of some major indicators. First of all, in this work, there are problems of importing energy resources to China. In [6] questions are raised about the problems of ensuring the energy security of Europe from the standpoint of the use of renewable energy resources. The paper analyzes the degree of participation in this process of the Desertec project (construction of the big solar power system in the Sahara). In [7] a general structure for the description and analysis of the energy security in an energy system is presented. The paper is devoted to the methodology of energy security research in the context of one system. Unlike energy independent Russia, it is important for most countries to monitor not only the structure of their energy balance. Particularly important is the share of the largest energy supplier in their total volume of energy resources import.

\section{The supposed features of the transformation of Russia's energy security threats until 2030}

Analysis of the situation with the transformation of ES threats due to various factors implies consideration of two aspects. The first aspect is the direction of the transformation of a specific threat in the time interval and the second is the change in the list of the most significant ES threats to Russia from one time interval to another. For each interval, a list of threats is formed and the main factors that enhance or weaken the threats are selected. The character of the transformation of a specific threat under the combined effect of various factors is assessed (strengthening - weakening, qualitative assessment of the degree of strengthening weakening). Then, based on the results of the assessment of the features of the ES threats transformation at both time intervals and taking into account the results of the earlier quantitative assessment of the change in the main indicators of the Russia's energy sectors in the period from 2018 to 2020, [2, 8] the forecast of numerical values of the same indices for 2025 and 2030 is given. It should be noted that with a formal approach, the number of factors taken into account when assessing the features of the transformation of one threat in one time interval

Corresponding author: ssm@isem.irk.ru 
may be extremely large. In this paper, the authors tried to take into account only the most significant factors with the qualitative assessment of the degree of their significance. When choosing a list of ES threats for consideration from 2021 to 2025, the degree of dependence of each chosen threat on the substance of the current economic crisis and on foreign policy factors was taken into account. Taking into account the real situation with the functioning of the fuel and energy complex in the period from 2011 to 2018, and the expected situation - from 2018 to 2020, the following threats were selected for consideration at this time interval:

-insufficient level of investment in the fuel and energy complex (FEC) of Russia;

- low rates of renewal of basic production assets (BPA) in FEC;
- energy wastefulness of the economy;

- significant gas dominance in the fuel and energy balances (FEB) of the regions of the European part of the Russia and the Ural;

- reduction of opportunities for gas production.

The results of an evaluation of the features of the ES threats transformation over a time interval from 2021 to 2025 are presented in Table 1 along with the main factors that determine the features of this transformation and the significance of each factor for this ES threat. The significance of the factors that enhance or reduce the ES threat is shown, respectively, as "- - -" and "+++" (pronounced significance), "- -" and "++" (medium significance), "-" and "+" (some significance).

Table 1. Assessment of the direction of transformation of the Russia's main ES threats in the period from 2021 to 2025

\begin{tabular}{|c|c|c|c|c|c|c|}
\hline \multirow[b]{2}{*}{ № } & \multirow[b]{2}{*}{ ES threat } & \multicolumn{2}{|l|}{ Factors of threat strengthening } & \multicolumn{2}{|c|}{ Factors of threat weakening } & \multirow{2}{*}{$\begin{array}{l}\text { Features } \\
\text { of the } \\
\text { threat } \\
\text { transfor- } \\
\text { mation }\end{array}$} \\
\hline & & Factor & $\begin{array}{l}\text { Degree } \\
\text { of threat } \\
\text { stren- } \\
\text { gthening }\end{array}$ & Factor & $\begin{array}{c}\text { Degree } \\
\text { of threat } \\
\text { weake- } \\
\text { ning }\end{array}$ & \\
\hline \multirow{4}{*}{1} & \multirow{4}{*}{$\begin{array}{l}\text { Insufficient } \\
\text { level of } \\
\text { investment in } \\
\text { FEC }\end{array}$} & $\begin{array}{l}\text { Unattractive business for investors } \\
\text { (corruption, raiding, monopolism) }\end{array}$ & «- - -» & $\begin{array}{l}\text { The expected growth in world } \\
\text { prices for hydrocarbons }\end{array}$ & «+» & \multirow{4}{*}{$\begin{array}{l}\text { Signifi- } \\
\text { cant } \\
\text { strengthe- } \\
\text { ning }\end{array}$} \\
\hline & & $\begin{array}{l}\text { Too much government role in } \\
\text { business management }\end{array}$ & $\langle---\rangle$ & $\begin{array}{l}\text { Not expected to significantly } \\
\text { increase domestic needs for fuel } \\
\text { and energy resources }\end{array}$ & $«++»$ & \\
\hline & & $\begin{array}{l}\text { The deterioration of hydrocarbon } \\
\text { reserves (the need to develop new } \\
\text { areas with a severe climate) }\end{array}$ & $\langle---»$ & \multirow[t]{2}{*}{$\begin{array}{l}\text { Adaptation of the economy to } \\
\text { functioning in the conditions of } \\
\text { economic crises }\end{array}$} & \multirow[t]{2}{*}{ «+» } & \\
\hline & & The basic production assets aging & «- -» & & & \\
\hline \multirow{4}{*}{2} & \multirow{4}{*}{$\begin{array}{l}\text { Low rates of } \\
\text { renewal of } \\
\text { BPA in FEC }\end{array}$} & $\begin{array}{l}\text { Insufficient level of investment in } \\
\text { FEC }\end{array}$ & $\langle---\rangle$ & \multirow{3}{*}{$\begin{array}{l}\text { Update of BPA in accordance } \\
\text { with the requirements of } \\
\text { industrial safety }\end{array}$} & \multirow{3}{*}{$«++»$} & \multirow{4}{*}{$\begin{array}{l}\text { Some } \\
\text { strengthe- } \\
\text { ning }\end{array}$} \\
\hline & & $\begin{array}{l}\text { Unattractive business for investors } \\
\text { (corruption, raiding, monopolism) }\end{array}$ & «- -» & & & \\
\hline & & $\begin{array}{l}\text { Reluctance of consumers to switch } \\
\text { from gas to other types of FER }\end{array}$ & 《- - » & & & \\
\hline & & $\begin{array}{l}\text { Lack of motivation to update obsolete } \\
\text { BPA (monopoly of suppliers, small } \\
\text { growth of domestic needs for FER) }\end{array}$ & «- -» & $\begin{array}{l}\text { Tougher environmental } \\
\text { requirements (for motor fuel, } \\
\text { heat and power generation) }\end{array}$ & $《++»$ & \\
\hline \multirow{2}{*}{3} & \multirow{2}{*}{$\begin{array}{l}\text { Energy } \\
\text { wastefulness } \\
\text { of the } \\
\text { economy }\end{array}$} & $\begin{array}{l}\text { Insufficient level of investment in } \\
\text { FEC }\end{array}$ & $\langle---\rangle$ & \multirow{2}{*}{$\begin{array}{l}\text { The growth of prices for FER } \\
\text { within the country } \\
\text { (deterioration of hydrocarbon } \\
\text { reserves, increase in production } \\
\text { costs) }\end{array}$} & \multirow{2}{*}{$«+++»$} & \multirow{2}{*}{$\begin{array}{l}\text { Some } \\
\text { weake- } \\
\text { ning }\end{array}$} \\
\hline & & $\begin{array}{l}\text { Technical backwardness from } \\
\text { developed countries }\end{array}$ & «- - » & & & \\
\hline \multirow{3}{*}{4} & \multirow{3}{*}{$\begin{array}{l}\text { The large gas } \\
\text { dominance in } \\
\text { the FEB of the } \\
\text { european } \\
\text { regions of the } \\
\text { Russia }\end{array}$} & $\begin{array}{l}\text { Low rates of renewal of BPA at the } \\
\text { basic consumers of gas (thermal } \\
\text { power stations, industrial boilers) }\end{array}$ & «- - 》 & \multirow{3}{*}{$\begin{array}{l}\text { The expected growth in the cost } \\
\text { of production and transport of } \\
\text { gas due to the development of } \\
\text { new production areas and the } \\
\text { reduction of gas reserves in old } \\
\text { areas }\end{array}$} & \multirow{3}{*}{ «+++» } & \multirow{3}{*}{$\begin{array}{l}\text { Some } \\
\text { weake- } \\
\text { ning }\end{array}$} \\
\hline & & $\begin{array}{l}\text { Large inertia of the transition from } \\
\text { gas to other fuels }\end{array}$ & «- - » & & & \\
\hline & & $\begin{array}{l}\text { The expected reduction of } \\
\text { opportunities for gas production }\end{array}$ & «- - 》 & & & \\
\hline \multirow{6}{*}{5} & \multirow{6}{*}{$\begin{array}{l}\text { Reduction of } \\
\text { opportunities } \\
\text { for gas } \\
\text { production }\end{array}$} & $\begin{array}{l}\text { Lagging with the development of gas } \\
\text { reserves in new areas and reducing } \\
\text { production levels in the old ones }\end{array}$ & «- - -» & & & \multirow{6}{*}{$\begin{array}{l}\text { Signifi- } \\
\text { cant } \\
\text { strengthe- } \\
\text { ning }\end{array}$} \\
\hline & & $\begin{array}{l}\text { The need to ensure domestic demand } \\
\text { for gas and export obligations }\end{array}$ & «- - -»» & & & \\
\hline & & $\begin{array}{l}\text { The expected growth in the cost of } \\
\text { production and transport of gas }\end{array}$ & «- - -»» & & & \\
\hline & & Insufficient level of investment & «- - » & & & \\
\hline & & $\begin{array}{l}\text { Increase in unit costs for new } \\
\text { construction }\end{array}$ & 《- - » & & & \\
\hline & & $\begin{array}{l}\text { Technical backwardness from } \\
\text { developed countries }\end{array}$ & 《- - » & & & \\
\hline
\end{tabular}


When considering the features of the ES threats transformation from 2026 to 2030, the authors added an additional threat. This is a reduction in opportunities for oil production in Russia, what reduces the possibilities for Russian oil export and exacerbates the problem of investment. The results of the assessment of the features of the Russia's ES strategic threats transformation from 2026 to 2030. under the combined effect of various factors are presented in Table 2, the method for assessing the significance of factors coincides with Table 1 .

Table 2. Assessment of the direction of transformation of the Russia's main ES threats in the period from 2026 to 2030

\begin{tabular}{|c|c|c|c|c|c|c|}
\hline \multirow[b]{2}{*}{ № } & \multirow{2}{*}{ ES threat } & \multicolumn{2}{|l|}{ Factors of threat strengthening } & \multicolumn{2}{|c|}{ Factors of threat weakening } & \multirow{2}{*}{$\begin{array}{l}\text { Features } \\
\text { of trans- } \\
\text { formation }\end{array}$} \\
\hline & & Factor & Degree & Factor & Degree & \\
\hline \multirow{3}{*}{1} & \multirow{3}{*}{$\begin{array}{l}\text { Insufficient } \\
\text { level of } \\
\text { investment in } \\
\text { FEC }\end{array}$} & Growth of domestic energy needs & «- -» & $\begin{array}{l}\text { Expected improvement of the } \\
\text { investment climate }\end{array}$ & $«+++»$ & \multirow{3}{*}{$\begin{array}{l}\text { Some } \\
\text { weake- } \\
\text { ning }\end{array}$} \\
\hline & & $\begin{array}{l}\text { Striving not to lose external markets } \\
\text { for hydrocarbons }\end{array}$ & «- -» & \multirow{2}{*}{$\begin{array}{l}\text { Increase in the share of oil and } \\
\text { gas refined products in the } \\
\text { structure of Russian FER export }\end{array}$} & \multirow{2}{*}{$«+++»$} & \\
\hline & & $\begin{array}{l}\text { The need to increase the share of } \\
\text { renewable energy sources }\end{array}$ & «-» & & & \\
\hline \multirow{2}{*}{2} & \multirow{2}{*}{$\begin{array}{l}\text { Low rates of } \\
\text { renewal of } \\
\text { BPA in FEC }\end{array}$} & $\begin{array}{l}\text { The lack of investment for replacing } \\
\text { obsolete BPA }\end{array}$ & «- -» & $\begin{array}{l}\text { The need to replace physically } \\
\text { obsolete BPA }\end{array}$ & $«+++»$ & \multirow{2}{*}{$\begin{array}{l}\text { Some } \\
\text { weake- } \\
\text { ning }\end{array}$} \\
\hline & & $\begin{array}{l}\text { Increasing requirements for the } \\
\text { replacement of obsolete BPA }\end{array}$ & «- -» & $\begin{array}{l}\text { Necessity of diversification of } \\
\text { energy sources, incl. renewable }\end{array}$ & $\ll++»$ & \\
\hline \multirow{4}{*}{3} & \multirow{4}{*}{$\begin{array}{l}\text { Energy } \\
\text { wastefulness } \\
\text { of the } \\
\text { economy }\end{array}$} & $\begin{array}{l}\text { Technical backwardness from } \\
\text { developed countries }\end{array}$ & «- » & \multirow{2}{*}{$\begin{array}{l}\text { The growth of prices for FER } \\
\text { within the country }\end{array}$} & \multirow{2}{*}{$«++»$} & \multirow{4}{*}{$\begin{array}{l}\text { Medium } \\
\text { weake- } \\
\text { ning }\end{array}$} \\
\hline & & $\begin{array}{l}\text { Growth of the need for FER within } \\
\text { the country }\end{array}$ & «- -» & & & \\
\hline & & $\begin{array}{l}\text { An anticipated increase in electricity } \\
\text { demand }\end{array}$ & «- -» & \multirow{2}{*}{$\begin{array}{l}\text { Decrease in opportunities for } \\
\text { hydrocarbon production, } \\
\text { motivation to increase energy } \\
\text { efficiency of the economy }\end{array}$} & \multirow{2}{*}{$«+++»$} & \\
\hline & & $\begin{array}{l}\text { A significant proportion of physically } \\
\text { and morally obsolete BPA }\end{array}$ & «- -» & & & \\
\hline \multirow{3}{*}{4} & \multirow{3}{*}{$\begin{array}{l}\text { The large gas } \\
\text { dominance in } \\
\text { the FEB of the } \\
\text { european } \\
\text { regions of the } \\
\text { Russia }\end{array}$} & $\begin{array}{l}\text { Reluctance of consumers to switch } \\
\text { from gas to other types of FER }\end{array}$ & 《- -» & $\begin{array}{l}\text { Decrease in the opportunities } \\
\text { for gas production in old areas }\end{array}$ & $«+++»$ & \multirow{3}{*}{$\begin{array}{l}\text { Some } \\
\text { weake- } \\
\text { ning }\end{array}$} \\
\hline & & $\begin{array}{l}\text { The price of gas inside the country is } \\
\text { less than its consumer value }\end{array}$ & 《- - » & $\begin{array}{l}\text { Delay with the development of } \\
\text { gas reserves in new areas }\end{array}$ & $«+++»$ & \\
\hline & & $\begin{array}{l}\text { The lack of funds to reduce the level } \\
\text { of gas domination }\end{array}$ & $《---»$ & $\begin{array}{l}\text { Rapid increase in the cost of gas } \\
\text { production and transportation }\end{array}$ & $«+++»$ & \\
\hline \multirow{10}{*}{5} & \multirow{10}{*}{$\begin{array}{l}\text { Reduction of } \\
\text { opportunities } \\
\text { for gas } \\
\text { production }\end{array}$} & $\begin{array}{l}\text { Rapid reduction in production levels } \\
\text { in the old areas }\end{array}$ & 《- - -» & \multirow{10}{*}{$\begin{array}{l}\text { Reduction in the volume of } \\
\text { exports of Russian gas for } \\
\text { external economic reasons }\end{array}$} & \multirow{10}{*}{$«+++»$} & \multirow{10}{*}{$\begin{array}{l}\text { Signifi- } \\
\text { cant } \\
\text { strengthe- } \\
\text { ning }\end{array}$} \\
\hline & & $\begin{array}{l}\text { Delay with the development of new } \\
\text { areas of gas production }\end{array}$ & $《---»$ & & & \\
\hline & & $\begin{array}{l}\text { Growth of Russia's internal needs in } \\
\text { primary FER }\end{array}$ & «- - -» & & & \\
\hline & & $\begin{array}{l}\text { The need to meet export obligations } \\
\text { for gas }\end{array}$ & «- - -» & & & \\
\hline & & $\begin{array}{l}\text { High cost of gas production and } \\
\text { transport for new regions }\end{array}$ & «- - -» & & & \\
\hline & & $\begin{array}{l}\text { Growth of needs for large } \\
\text { investments }\end{array}$ & «- - -» & & & \\
\hline & & $\begin{array}{l}\text { Technical backwardness from } \\
\text { developed countries }\end{array}$ & 《- - » & & & \\
\hline & & The large gas dominance in the FEB & $《-»$ & & & \\
\hline & & $\begin{array}{l}\text { Inertia of the main consumers in the } \\
\text { transition from gas to other FER }\end{array}$ & «- - -» & & & \\
\hline & & $\begin{array}{l}\text { The development of gas chemistry } \\
\text { with an increase in the share of gas as } \\
\text { raw material }\end{array}$ & «- - 》 & & & \\
\hline \multirow{4}{*}{6} & \multirow{4}{*}{$\begin{array}{l}\text { Reduction of } \\
\text { opportunities } \\
\text { for oil } \\
\text { production }\end{array}$} & Deterioration of the developed oil & & $\begin{array}{l}\text { Development of non-primary } \\
\text { sources of income in the GDP } \\
\text { structure }\end{array}$ & «+» & \multirow{4}{*}{$\begin{array}{l}\text { Some } \\
\text { strengthe- } \\
\text { ning }\end{array}$} \\
\hline & & $\begin{array}{l}\text { reserves, the need to develop areas } \\
\text { with severe climatic conditions }\end{array}$ & 《----» & $\begin{array}{l}\text { Reduction of demand for oil in } \\
\text { the world (hybrid technologies } \\
\text { and electric vehicles) }\end{array}$ & $\ll++»$ & \\
\hline & & \multirow{2}{*}{$\begin{array}{l}\text { The technical backwardness of Russia } \\
\text { in the use of new technologies for oil } \\
\text { production }\end{array}$} & & $\begin{array}{l}\text { Increase in the depth of oil } \\
\text { refining }\end{array}$ & «+» & \\
\hline & & & «- - -» & $\begin{array}{l}\text { Increase in the share of finished } \\
\text { petroleum products in the } \\
\text { export of liquid hydrocarbons }\end{array}$ & «+» & \\
\hline
\end{tabular}




\section{The impact of the ES threats transformation on the development of FEC with a more detailed consideration of the gas industry}

As for the features of the ES threats transformation, let us consider the gas industry. In comparison with 2020, we can expect here a strengthening of the negative significance of the delay factor with the development of new areas of gas production. This will lead to a reduction in opportunities for gas production. Taking into account the results of such an assessment and taking into account the results of the forecast of the Russia's FEC functioning for the period up to 2020, we will try to estimate the characteristics of its functioning for the reference years until 2030. The results of the forecast for domestic needs of the country in primary FER for 2020 are $1010 \mathrm{mln}$ tce [2]. Herewith, we believe that the average annual (in 2018-2020) values of GDP growth rates $\left(\mathrm{K}_{\mathrm{GDP}}\right)$ and reduction of specific energy intensity of GDP $\left(K_{\mathrm{SEI}}\right)$ will be: $\mathrm{K}_{\mathrm{GDP}}-1.02$, and $\mathrm{K}_{\mathrm{SEI}}-0.01$.

Taking into account a certain easing of the threat of the energy wastefulness of the Russian economy for the period from 2021 to 2025, the value of $K_{\text {SEI }}$ will be equal to 0,015, and for the period from 2026 to 2030 it will be equal to 0,02 . Due to lack of investment in 20212030 it is difficult to expect a noticeable growth in the economy. Therefore, the annual growth of GDP at this time can't be significant. It was adopted for 2021-2026 the average annual value of $\mathrm{K}_{\mathrm{GDP}}=1.025$, for the period from 2026 to 2030 it can be $\approx 1,035$. Then domestic demand for primary FER will be: for 2025 - 1070, and for 2030 - 1150 mln tce.

The oil industry is involved in covering the domestic needs of the country in primary fuel and energy resources through the required volumes of oil to produce light petroleum products for domestic use. These volumes are determined by the country's annual demand for these oil products and their share of output when refining oil at the Russian refineries. We can't expect a noticeable increase in the demand for light oil products (due to the expected increase in the share of electricity in the structure of FER consumed by transport) from 2021 to 2030 . We believe that the annual increase in demand for light oil products in 2021-2025. will be $1.5-2 \%$, and from 2026 to 2030. - 0.5-1.5\%. The output of light oil products on average in Russia for 2020 was adopted by $58 \%$ [8, 9, etc.]. On average, this year's output from 2021 to 2025. we will take 60\%, and from 2026 to 2030. - $63 \%$. As a result, the required volumes of oil for the production of light petroleum products for domestic use are obtained at the level of $137 \mathrm{mln}$ t in 2025 and 135 mln $t$ in 2030. These volumes of oil are much less than what is produced in Russia today (540-550 mln t). The features of the ES threats transformation show that the opportunities for the extraction of liquid hydrocarbons in Russia will be reduced with some acceleration of the rate of decline. In 2025, we can expect a production level of about $500 \mathrm{mln} \mathrm{t}$, and by 2030 production could be reduced to $450 \mathrm{mln}$ t per year. Of course, these volumes are much larger than domestic needs.
The available volumes of natural gas for use within Russia and for its exports will be determined by the level of its production in the old regions, as well as by the rates of development of new gas and the volume of imported gas, Table 3.

Table 3. Actual (2017) and expected available gas volumes in Russia for domestic use and exports from 2020 to 2030, bcm

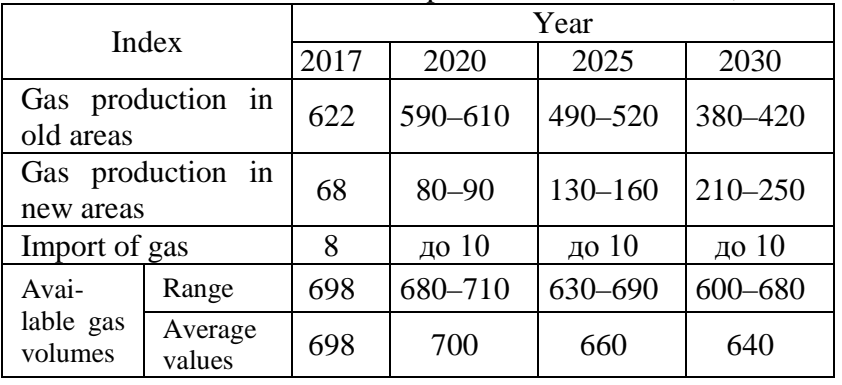

When forming a Table 3, the results of the evaluation of the features of the ES Russia's threats transformation from 2021 to 2030 are taken into account related to: the reduction of opportunities for gas production; lack of investment and unsatisfactory rates of development of new gas production areas. When assessing the quantitative indicators for gas production in the old areas, the following points were taken into account:

- expected volumes of gas production in 2020 (taking into account [2] and date of 2017);

- $\quad$ it is possible to reduce the previously predicted $[4,5]$ gas production growth rates on Sakhalin from 80-100 to $50-70$ bcm (by 2030);

- the total gas production in operating fields of the Krasnoyarsk Territory, Yakutia and Tomsk Oblast will not exceed $10 \mathrm{bcm}$ per year until 2030, and the total volume of natural gas production in other regions (Astrakhan Region, Orenburg Region, Komi Republic, etc.) ) can reach 20-40 bcm (by 2030).

When assessing gas production levels in new areas, the following factors were taken into account:

- due to investment difficulties in the previous decade (2011-2020), the annual production levels in Yamal by 2030 will not exceed 140-170 bcm per year;

- by 2025, gas production at the Kovykta field (Irkutsk region) should begin;

- by 2030 it is necessary to start development of the Shtokman field on the Barents Sea shelf to compensate for the falling gas production at currently developed fields.

The participation of coal in providing Russia's domestic needs for primary FER will not be as significant as gas, although beyond 2020 its consumption inside the country should increase (it is necessary to work to neutralize one of the most important ES threats gas domination in the FEB of most regions of Russia). At the same time, the growth in coal consumption will not be very noticeable: in 2021-2025 the average annual increase in coal consumption will not exceed 0.5-1.0\%, and in 2026-2030 - 1.5-2\%. By 2030, the growth in export levels of Russian coal may stop.

The total annual production of primary FER in Russia at hydroelectric power plants (HPPs) and nuclear power plants (NPPs) (electric power) and other FER 
(firewood, peat, non-traditional), which are also involved in domestic demand for primary energy resources, have changed insignificantly for many years (70-75) mln toe per year. In 2017, these volumes were $71 \mathrm{mln}$ toe [8, 9], most likely in 2020 they will be just over $70 \mathrm{mln}$ toe [2]. Taking into account the expected growth in the share of non-traditional fuel and energy resources (especially in the period from 2025 to 2030) and a certain increase in electricity production at HPPs and NPPs, the total volumes in 2025 may amount to $75-80 \mathrm{mln}$ toe and in 2030 - 90-100 mln toe.

The expected available capacities of the energy industries to cover the long-term needs in primary fuel and energy resources are shown in Table 4.

Table 4. Expected capabilities of Russia's energy industries to ensure its domestic needs in primary energy resources with the focusing on opportunities for the export of Russian gas

\begin{tabular}{|c|c|c|c|}
\hline \multirow{2}{*}{ Index } & \multicolumn{3}{|c|}{ Year } \\
\hline & 2020 & 2025 & 2030 \\
\hline $\begin{array}{l}\text { Required volumes of oil for } \\
\text { production of light petroleum } \\
\text { products for domestic use, mln t } \\
\text { mln toe }\end{array}$ & $\begin{array}{l}130 \\
180\end{array}$ & $\begin{array}{l}140 \\
200\end{array}$ & $\begin{array}{l}140 \\
200\end{array}$ \\
\hline $\begin{array}{l}\text { Available volumes of gas (to } \\
\text { cover domestic needs in primary } \\
\text { FER and for export), bcm } \\
\begin{array}{l}\text { mln toe }\end{array}\end{array}$ & $\begin{array}{l}700 \\
830\end{array}$ & $\begin{array}{l}660 \\
790\end{array}$ & $\begin{array}{l}640 \\
760\end{array}$ \\
\hline $\begin{array}{l}\text { Available volumes of coal to } \\
\text { cover the domestic needs in } \\
\text { primary FER, } \\
\end{array}$ & $\begin{array}{l}230 \\
140\end{array}$ & $\begin{array}{l}240 \\
150\end{array}$ & $\begin{array}{l}270 \\
170\end{array}$ \\
\hline $\begin{array}{l}\text { Possibilities of HPPs, NPPs and } \\
\text { other FER to participate in } \\
\text { covering domestic needs in } \\
\text { primary FER, } \\
\end{array}$ & 70 & 80 & 100 \\
\hline $\begin{array}{l}\text { Total capabilities of Russia's } \\
\text { energy industries to ensure its } \\
\text { domestic needs for primary FER } \\
\text { and to ensure gas exports, mln toe }\end{array}$ & 1220 & 1220 & 1230 \\
\hline $\begin{array}{l}\begin{array}{l}\text { Domestic needs of } \\
\text { primary FER, }\end{array} \\
\text { mln toe }\end{array}$ & 1010 & 1070 & 1150 \\
\hline $\begin{array}{l}\text { Russia's ability to export gas, } \\
\qquad \mathrm{mln} \text { toe } \\
\text { bcm }\end{array}$ & $\begin{array}{l}210 \\
\mathbf{1 8 0}\end{array}$ & $\begin{array}{l}150 \\
\mathbf{1 3 0}\end{array}$ & $\begin{array}{l}80 \\
70\end{array}$ \\
\hline
\end{tabular}

In Table 4 the opportunities of all branches of the Russia's FEC are compared with its internal needs in primary FER from 2020 to 2030. On this basis, the country's export capabilities for gas for the same time are shown. Of particular concern is the fact that the opportunities for exporting Russian gas (without taking into account the situation on the external markets and provided that the domestic needs of the country are fully met in gas) can be significantly reduced. Without the adoption of special cardinal measures, this value by 2030 may be only about $70 \mathrm{bcm}$ per year.

\section{Conclusion}

In the conditions of investment deficit in Russia and in the context of the implementation of various Russia's ES threats, justification of the required cardinal measures is extremely difficult and responsible. The task is to select the appropriate priorities. If, among other things, we take into account the importance of gas for the Russia's economy today and the colossal inertia of the country's FEC development up to 2030 the following main priorities in ensuring the Russia's ES can be singled out:

- significant improvement with investments in FEC;

- decrease in the share of gas in the Russia's FEB due to a certain increase in the share of coal and nontraditional fuel in these balances;

- prevention of reduction of opportunities for gas production, incl. due to more accelerated rates of development of new areas of gas production (Yamal and Gydan Peninsulas, the shelf of the Barents and Kara Seas).

A comprehensive analysis of the real situation with ensuring the country's energy security from 2011 to 2017 and the expected situation until 2030 makes not to ignore such moments as:

- the ability of FEC to provide consumers with the required kinds of FER in the required quantities during non-standard, cold periods;

- reduction of opportunities for oil production;

- creation of conditions (organizational and legislative) to prevent strikes at energy facilities, non-payments in domestic energy markets and unreasonably high domestic prices for certain types of FER;

- creation of conditions for the prevention of emergency situations at FEC facilities, including conditions for the prevention of terrorist acts at these facilities.

The work was carried out within the framework of a scientific project III.17.5.1 of program of fundamental research of the SB RAS, reg. number AAAA-A17-117030310451-0.

\section{References}

1. Rabchuk V.I., Senderov S.M., Vorobev S.V., Energeticheskaya Politika[Energy Policy], 1, 84-94 (2017).

2. Senderov S.M., Rabchuk V.I., Pyatkova N.I., Vorobev S.V. Ensuring Russia's energy security: choosing priorities (Nauka Publ., Novosibirsk, 2017).

3. Senderov S.M., Edelev V.A., Energy Systems Research, 1, 35-43 (2018).

4. Bambawale M.J., Sovacool B.K., Energy Policy, 39 (3), 1254-1264 (2011).

5. Leung G.C.K., Energy Policy. 39 (3), 1330-1337 (2011).

6. Lilliestam J., Ellenbeck S., Energy Policy, 39 (6), 3380-3391 (2011).

7. Hughes L., Energy Policy. 42 (C), 221-231 (2012).

8. Ministry of Energy of the Russian Federation. Statistics. Available at: http://minenergo.gov.ru/ activity/statistic. (Accessed 12 May 2018).

9. Novak A.V. Available at: https://minenergo.gov.ru/node/11279. (Accessed 30 May 2018). 